\title{
SETS approach-based audiovisual media for improving the students' critical thinking skills
}

\author{
Sri Suriawati *, Mundilarto Mundilarto \\ Universitas Negeri Yogyakarta. Jalan Colombo No 1, Karangmalang, Yogyakarta, 55281, Indonesia \\ * Corresponding Author. E-mail: suria2711@gmail.com
}

Received: $6^{\text {th }}$ September 2018; Revised: $20^{\text {th }}$ February 2019; Accepted: $22^{\text {nd }}$ August 2019

\begin{abstract}
Through the conduct of the study, the researchers aim at: (1) developing audiovisual media through well-qualified SETS approach so that the audiovisual media will be feasible for implementation; (2) identifying the level of the students' critical thinking skills after the students have made use of the SETS approach-based audiovisual media; and (3) identifying the differences on the level of the critical thinking skills between the students who make use of the SETS approach-based audiovisual media and the students who do not make use of the SETS approachbased audiovisual media. This study is a Research \& Development (R\&D) initiative that refers to seven steps as follows: (1) gathering the necessary information; (2) designing the product; (3) developing the preliminary product; (4) performing preliminary field experiment; (5) revising the product based on the preliminary experiment results; (6) performing the main field experiment; and (7) revising the product based on the main field experiment results. After the overall process in the study has been completed, the results of the study show that: (1) the SETS approach-based audiovisual media has already met the feasibility criteria; (2) the achievement on the students' critical thinking skills after the implementation of the SETS approach-based audiovisual media is 0.25; and (3) there have been differences on the level of the critical thinking skills between the students who make use of the SETS approach-based audiovisual media and the students who do not make use of the SETS approach-based audiovisual media.
\end{abstract}

Keywords: audiovisual media, SETS, critical thinking skills

How to Cite: Suriawati, S., \& Mundilarto, M. (2019). SETS approach-based audiovisual media for improving the students' critical thinking skills. Psychology, Evaluation, and Technology in Educational Research, 1(2), 95-103. doi:http://dx.doi.org/10.33292/petier.v1i2.15

\section{INTRODUCTION}

The development of science and technology has brought about numerous changes in almost all life aspects (Ngafifi, 2014). These changes result in a number of solutions that might be proposed for solving the problems through the mastery and the advancement of science and technology. In the same time, the development and the improvement of human resources through the improvement on the education quality is a strategic effort in order that the graduates of any educational degree might join the global competition nowadays.

Departing from this situation, teaching and learning process are two concepts that might not be separated from one to another. Learning refers to what an individual should perform as an educational subject that retrieves the lesson (educational target) (Setiawan, 2010), while teaching refers to what a teacher should perform as an educator (Misbah, 2006). Teachers might make use of a number of learning media in facilitating the teaching-learning process in the school; consequently, teachers might have effective and polite communication and interaction and this also applies in the case of information technology utilization (Badan Standar Nasional Pendidikan, 2006).

Based on the results of the observation Negeri 1 Bantul Public Senior High School, the researchers have gathered information that the learning method has still been dominated by the conventional one namely that the learning process still centers on the teachers and the teachers are 
accustomed to lecturing in front of the students. These methods place teachers as the information source and students as the information retriever. Not to mention, the discussion process has also been dominated by certain students and the other students only become the listeners; if these listeners are asked to speak out their opinion, they will suffer from certain difficulties.

Furthermore, based on the results of the observation the researchers have found that there have been facilities that support the conduct of the teaching-learning process namely LCD (Liquid Crystal Display) and speakers. The facilities in a school is one of the aspects that provide significant support for the learning process. Within the learning process, media play a significant role in achieving the learning objectives. The relationship that lies in the communication between the teachers and the students will be better and more efficient if media are put in the relationship (Rusman \& Riyana, 2011). However, the lack of learning facilities utilization, especially the audiovisual media, has caused the learning process to be less effective and less interesting for the students. As a result, the students become bored and less interested in attending to the learning process and this situation leads to the low learning achievement. Therefore, audiovisual media are expected to facilitate the students' understanding and to improve the students' memory retention so that eventually the students might optimize their potentials and capacities (Budiana, 2019; Haryoko, 2012). The reason is that audiovisual media refers to the representation of reality, especially through vision and audio, that aims at displaying the actual educational experience to the students (Abdulhak \& Darmawan, 2013).

Specific to the context of the study, Physics learning process aims at facilitating the students to master concepts of Physics so that they might actually implement these concepts in the routines of their daily life. In relation to the statement, the SETS (Science, Environment, Technology and Society) provides an opportunity for the students to attain knowledge and also critical and performing skills altogether in the same time based on the results of the comprehensive synthesis and analysis through the calculation on the aspects of science, environment, technology and society as a single and inseparable entity (Binadja, 2006, 2009). The peculiarity of the SETS approach is that in the introductory part the students are exposed to the issues or the problems that have taken in the daily life of the society and these problems might be uncovered from the students or might be uncovered by the teachers if the students do not find any example (Poedjiadi, 2005).

Furthermore, critical thinking skills refer to the capacities, the skills and the actions of the students that include the capability to identify equation and disequation, to provide reasons, to draw inductive and deductive conclusion, to identify the content validity of a definition and to formulate alternative solutions in solving the existing problems in within the scientific learning process around the context of the students' daily life. Looking at the description, the learning process by means of SETS implies that the students are encouraged to use the scientific concepts in the form of technology for meeting the needs of the society along with the consideration toward the implication of the technology onto the environment. In order that the learning process by means of SETS might be optimally performed, teachers might utilize the audiovisual media as the alternative learning media.

\section{METHOD}

The method that had been implemented in the study was research and development (Gall, Gall, $\&$ Borg, 2003). The study took place on April 29 $9^{\text {th }}, 2014$, and May 6 ${ }^{\text {th }}, 2014$ in Negeri 1 Bantul Public Senior High School. Within the study, the researcher involved two classrooms namely X Natural History 7 as the experimental group with the number of students 27 people and X Natural History 4 as the control group with the number of students 28 people.

The procedures that had been implemented in the study were automatically the research and development procedures as follows: (1) gathering information (through classroom observation); (2) designing the product (formulating the research objectives and calculating the necessary amount of time and fund); (3) developing the preliminary product (designing the preliminary draft of the product); (4) performing the preliminary field experiment; (5) revising the product based on the results of the preliminary field experiment; (6) performing the main field experiment; and (7) revising the product based on the results of the main field experiment.

Within the conduct of the study, validation sheet was designed in order to attain the data on the audiovisual media feasibility from the results of the development. The validation was based on the aspects of learning materials and of learning media. The validation sheet took the form of 
questionnaire and later the questionnaire was distributed to the material expert, the media expert, the Physics teachers and the research colleagues. On the other hand, the assessment sheet was designed for the students in the limited experiment and the expanded experiment in order to assess the audiovisual media feasibility from the perspective of the layout quality and the material presentation within the audiovisual media. The two instruments were designed by referring to the Likert scale.

The pre-test and the post-test sheet were distributed in order to identify the results of the students' critical thinking skills in relation to the aspects of the students' critical thinking skills (Nitko $\&$ Brookhart, 2011). The aspects or the guidelines for assessing the students' critical thinking skills might be consulted in Table 1 .

Table 1. Guidelines for the Assessment of the Critical Thinking Skills in the Pre-Test and the Post-Test Activities

\begin{tabular}{|c|c|c|}
\hline $\begin{array}{l}\text { Category of Critical } \\
\text { Thinking Skills }\end{array}$ & $\begin{array}{l}\text { Indicators of Critical } \\
\text { Thinking Skills }\end{array}$ & $\begin{array}{c}\text { Sub-Indicators of Critical } \\
\text { Thinking Skills }\end{array}$ \\
\hline Providing simple explanation & Argumentation & Looking for similarities and differences \\
\hline Basic skills & $\begin{array}{l}\text { Comparing the credibility of each } \\
\text { source }\end{array}$ & Being able to provide reasons \\
\hline Conclusion drawing & $\begin{array}{l}\text { Creating deduction and } \\
\text { comparing induction }\end{array}$ & $\begin{array}{l}\text { Drawing conclusions inductively } \\
\text { Drawing conclusions deductively }\end{array}$ \\
\hline Further clarification & Defining terms & $\begin{array}{l}\text { Identifying the content validity of a } \\
\text { definition }\end{array}$ \\
\hline Arranging tactics and strategies & Defining actions & Formulating alternatives of solution \\
\hline
\end{tabular}

On the other hand, the observation sheet of the students' critical thinking skills was designed in order to assess the students' critical thinking skills during the learning process in the conduct of the field experiment. The aspects that had been observed in assessing the students' critical thinking skills were all of the aspects in the students' critical thinking skills (Nitko \& Brookhart, 2011). The indicators in the observation might be consulted in Table 2 .

Table 2. Guidelines for the Assessment of the Students' Critical Thinking Skills in the Observation Activities

\begin{tabular}{ll}
\hline \multicolumn{1}{c}{ Category of Critical Thinking Skills } & \multicolumn{1}{c}{ Indicators of Critical Thinking Skills } \\
\hline Providing simple explanation & Argumentation \\
Basic skills & Comparing the credibility of each source \\
Conclusion drawing & Creating deduction and comparing induction \\
Further clarification & Defining terms \\
Arranging tactics and strategies & Defining actions \\
\hline
\end{tabular}

\section{Data Analysis Technique}

Analysis on the Audiovisual Media Feasibility

The assessment by the media expert, the material expert, the Physics teachers, the colleagues and the students on the SETS approach-based audiovisual media feasibility was conducted in three steps. In the first step, the validators assessed the feasibility by means of tabulation, namely inputting all the data that had been attained from all validators for each component of the available assessment items in the instrument. Then, in the second step the researchers calculated the mean score of each aspect by using the following formula:

$\bar{x}=\frac{\sum x}{n}$

Note:

$\bar{x} \quad=$ mean score of each indicator

$n \quad=$ number of variables

$\sum x=$ score of each indicator

Next, in the third step, the researchers attained the data from the Likert scale and these data were converted into four criteria of reference (Mardapi, 2008). The four criteria might be consulted in Table 3. 
Psychology, Evaluation, and Technology in Educational Research, 1 (2), 2019, 98

Sri Suriawati, Mundilarto Mundilarto

Table 3. The Conversion from the Score into the Ideal Assessment

\begin{tabular}{ccc}
\hline No. & Score Interval & Category \\
\hline 1. & $\mathrm{X}>\overline{\mathrm{x}}+1,25 \mathrm{SBx}$ & Very Good \\
2. & $\overline{\mathrm{x}}+1.25 \mathrm{SBx}>\mathrm{X} \leq \overline{\mathrm{x}}$ & Good \\
3. & $\overline{\mathrm{x}}>\mathrm{X} \geq \overline{\mathrm{x}}-1.25 \mathrm{SBx}$ & Moderate \\
4. & $\mathrm{X}<\overline{\mathrm{x}}-1.25 \mathrm{SBx}$ & Poor \\
\hline
\end{tabular}
Note:

$X \quad:$ the score that has been achieved

$\bar{x} \quad: \frac{1}{2}$ (maximum score + minimum score)

$S B x: \frac{1}{5}$ (maximum score-minimum score)

Analysis on the Observation Sheet

The observation sheet of the learning process accomplishment was implemented in order to observe the conduct of the learning activities with reference to the indicators of the students' critical thinking skills. The assessment on the observation results was performed in accordance to the descriptors that had been implemented within the learning activities. The percentage scale for defining the learning process accomplishment referred to the Formula 1:

$\%$ of implementation $=\frac{\text { number of implemented descriptors }}{\text { number of desciptors }} \times 100 \%$

Analysis on the Improvement of the Students' Critical Thinking Skills

In order to identify the improvement on the students' critical thinking skills within the study, the researchers implemented the normalized gain score technique or the score normalization $\langle\mathrm{g}\rangle$ (Hake, 2002). By identifying the mean score of the $\langle\mathrm{g}\rangle$ value, the improvement on the students' critical thinking skills might be identified. The $\langle\mathrm{g}\rangle$ value might be calculated by using the Formula (2) below. From the calculation by means of Formula 2, the researchers found that $\langle\mathrm{g}\rangle$ refers to the normalized gain value, the post-score $(\%)$ refers to the Post-Test results percentage and the pre-score $(\%)$ refers to the pre-test results percentage.

$<g>=\frac{\text { Postscore }(\%)-\text { Prescore }(\%)}{100 \%-\text { Prescore }(\%)}$

The criteria for the normalized gain $\langle\mathrm{g}\rangle$ value might be consulted in Table 4 .

Table 4. Index of Normalized Gain $<\mathrm{g}>$ Value

\begin{tabular}{cc}
\hline Index $<\mathrm{g}>$ & Criteria \\
\hline$<\mathrm{g}>\geq 0,70$ & High \\
$0,30<<\mathrm{g}><0,70$ & Moderate \\
$<\mathrm{g}>\leq 0,30$ & Low \\
\hline
\end{tabular}

Then, the requirements for the conduct of the independent sample t-test consisted of the normality test and the homogeneity test. The conduct of the hypothesis test by using the independent sample t-test analysis was run by means of SPSS 20.0 and the hypothesis formulation was as follows:

Ho : $\mu_{1} \leq \mu_{2}$ implies that the improvement of the critical thinking skills for the students who are exposed to the SETS approach-based audiovisual media is equal to or lower than the improvement of the critical thinking skills for the students who are not exposed to the SETS approach-based audiovisual media.

Ha : $\mu_{1}>\mu_{2}$ implies that the improvement of the critical thinking skills for the students who are exposed to the SETS approach-based audiovisual media is higher than the improvement of the critical thinking skills for the students who are not exposed to the SETS approach-based audiovisual media.

Note:

$\mu_{1}=$ the mean score of the critical thinking skills from the students in the experimental group (the students who are exposed to the SETS approach-based audiovisual media) 
$\mu_{2}=$ the mean score of the critical thinking skills from the students in the control group (the students who are not exposed to the SETS approach-based audiovisual media)

Analysis and Discussions

The data analysis for the results of the learning media product is based on the following aspects of learning media: (1) screen design effectiveness and ease of operation; (2) navigation effectiveness; and (3) media usefulness. The data summary might be consulted in Figure 1.

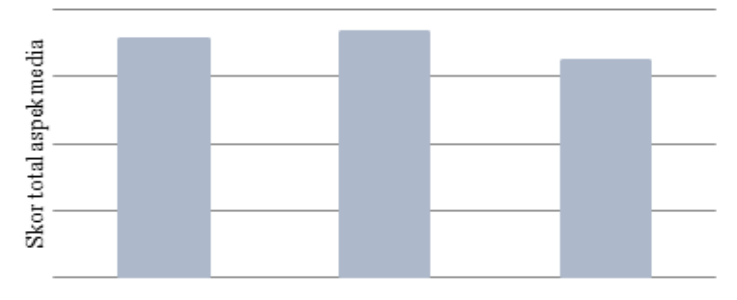

Penilai

Figure 1. Diagram for the Results of Audiovisual Media Assessment from the Aspect of Learning Media

From the results of the assessment by the media expert, the total score for the product is 71.50 . According to the assessment scale, the product belongs to the "Very Good" category. Then, from the results of the assessment by the Physics teachers, the total score for the product is 73.50. According to the assessment scale, the product score belongs to the "Very Good" category. Last but not the least, from the results of the assessment by the colleagues, the total score for the product is 65.00. According to the assessment scale, the product score belongs to the "Very Good" category.

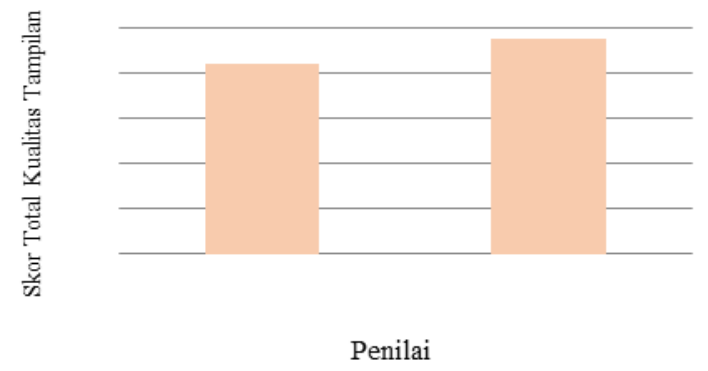

Figure 2. Diagram for the Results of Student Assessment toward the Layout Quality

From the results of the assessment by the students in the limited experiment, the total score for the layout quality is 23.00 . According to the assessment scale, the product belongs to the "Very Good" category. Then, from the results of the assessment by the students in the expanded experiment or the field experiment, the total score for the layout quality is 23.80 . According to the assessment scale, the product belongs to the "Very Good" category.

In overall, the assessment toward the audiovisual media aspect and the media aspect has shown maximum results since the assessment by the media expert falls into the "Very Good" category, the assessment by the Physics teachers falls into the "Very Good" category and the assessment by the colleagues falls into the "Very Good" category. In the same time, the assessment by the students in the limited experiment and also by the students in the expanded experiment or the field experiment also fall into the "Very Good" category.

The appropriate selection of background color and font color is very useful for the graphical layout in the learning media, improves the user interaction and focuses the students' attention. Blue has been selected as the background color because this color is able to influence perception, to provide soothing effect and to serve as a contrastive color for white (font color) so that the font might be read easily.

Figures might be manipulated in order to draw interest, clarify idea and material presentation and illustrate facts. The user manual in the audiovisual media that has been implemented facilitates the 
students to learn the material of heat transfer by means of SETS approach; automatically, the criteria of navigation effectiveness have been met. Then, the simulation in the audiovisual media also provides interesting feedback for the students; this feedback provides opportunity for the students to have direct interaction with the learning media, provides freedom for the students to use the audiovisual media independent and triggers the students' learning interest.

On the other hand, based on the assessment by the material expert, the total score for the media is 35.00, which, according to the assessment scale, belongs to the "Good" category. Then, based on the assessment by the Physics teachers, the total score for the media is 30.00, which, according to the assessment scale, belongs to the "Good" category. Last but not the least, based on the assessment by the colleagues, the total score for the media is 35.00, which, according to the assessment scale, belongs to the "Good" category. The complete results of the total score from each validator might be consulted in Figure 3.

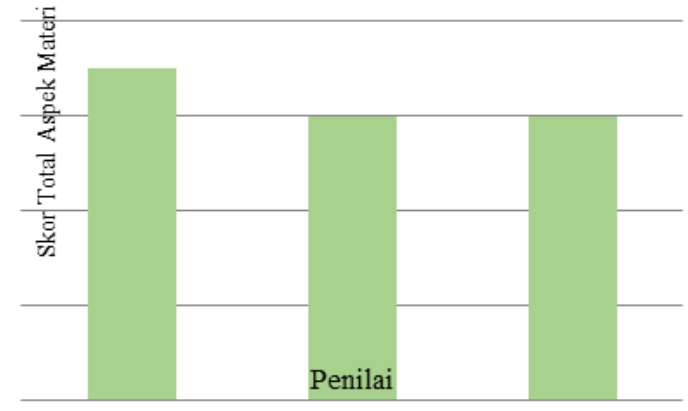

Figure 3. Diagram for the Audiovisual Media Assessment Results on the Aspect of Material

In relation to the Figure 3, the results of the assessment by the students in the limited experiment show that the total score for the material presentation is 25.90. According to the assessment scale, the audiovisual media belongs to the "Good" category. Then, rather contradictory, the results of the assessment by the students in the expanded experiment or the field experiment show that the total score for the audiovisual media is 26.40. According to the assessment scale, the audiovisual media belongs to the "Very Good" category. The complete results for the assessment by the students in the limited experiment and by the students in the expanded experiment or the field experiment might be consulted in Figure 4.

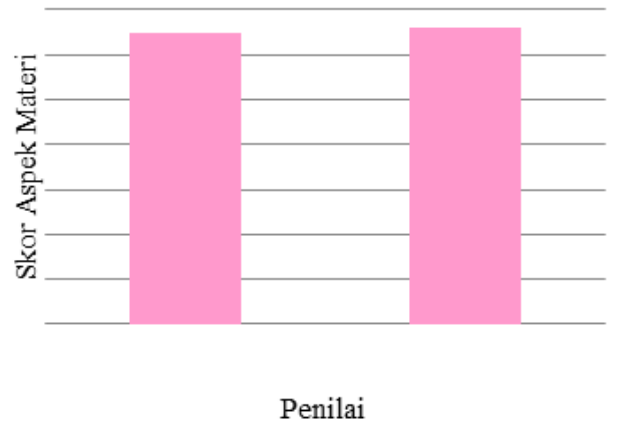

Figure 4. Diagram for the Audiovisual Media Assessment Results on the Aspect of Material Presentation

In overall, the assessment toward the audiovisual media from the aspects of material has shown good result since the assessment provided by the media expert shows "Good" category and the assessment by the Physics teachers shows "Good" category as well. In the same time, the results of the student assessment in the limited experiment and of the student assessment in the expanded experiment or the field experiment also show "Good" category. These results confirm that the materials in the audiovisual media that have been developed are able to meet the students' needs toward the learning materials of Heat Transfer by means of SETS approach.

According to the results of the assessment, the audiovisual media is easy to learn and the materials in the audiovisual media are in accordance to the learning process that has been delivered. The materials presentation is interesting and in accordance to the layout criteria with the support from 
the diction, the appropriate language for the students' age and also the appropriate color, pictures and videos for the materials and the simulation. The complexity of the learning materials that have been delivered to the students might be simplified with the media assistance. Thereby, the students are easier to digest the materials rather than reading throughout the learning materials.

Next, the results of the observation on the students' activities show that the implementation of the students' activities in the first meeting is $75.00 \%$ and in the second meeting is $85.00 \%$. These results show that in both meetings the students' activities might be well implemented and the students show positive activities.

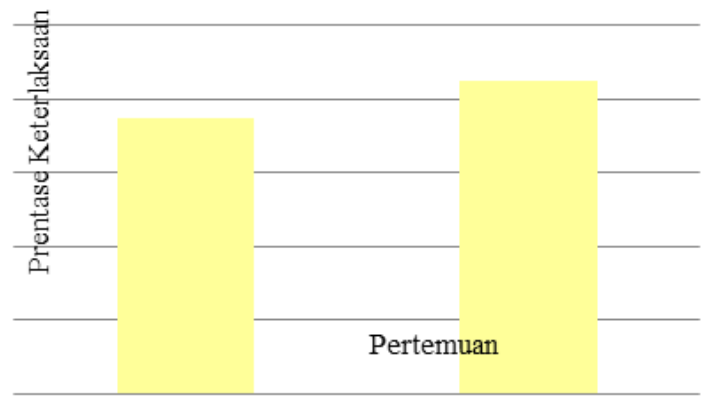

Figure 5. Diagram on the Results of Observation for the Implementation of the Students' Activities

The data on the students' critical thinking skills for both the experimental group and the control group are analyzed by performing the hypothesis test toward the standard gain value through SPSS 20.0. The analysis is conducted in order to identify the improvement on the students' critical thinking skills. Prior to the conduct of the hypothesis test, the researchers should perform the analysis prerequisite test. The analysis prerequisite test consists of normality test and homogeneity test.

Then, the pre-test score and the post-test score are calculated in order to identify the effectiveness of the learning media product that has been developed for improving the students' critical thinking skills. In addition, the pre-test score and the post-test score are also calculated in order to identify the differences on the improvement of the critical thinking skills between the students who have been exposed to the audiovisual media and the students who have not been exposed to the audiovisual media within the learning process.

Table 5. Description on the Data of the Students' Pre-Test, Post-Test and Standard Gain Score

\begin{tabular}{clrrrrrr}
\hline \multirow{2}{*}{ No. } & \multirow{2}{*}{ Description } & \multicolumn{3}{c}{ Experimental Group } & \multicolumn{3}{c}{ Control Group } \\
\cline { 3 - 7 } & Pretest & Posttest & Gain & Pretest & Posttest & Gain \\
\hline 1. & Number of students & 27.00 & 27.00 & - & 28.00 & 28.00 & - \\
2. & Mean & 35.00 & 50.00 & 0.25 & 30.00 & 40.00 & 0.17 \\
3. & Standard deviation & 7.50 & 6.10 & 0.08 & 8.24 & 6.28 & 0.09 \\
4. & Minimum score & 15.00 & 40.00 & 0.14 & 15.00 & 25.00 & 0.01 \\
5. & Maximum score & 50.00 & 65.00 & 0.44 & 45.00 & 55.00 & 0.40 \\
\hline
\end{tabular}

The analysis is performed by using the SPSS 20.0. The pre-test score is taken the beginning of the first meeting, while the post-test score is taken at the end of the last meeting. Then, the normality test is performed by running the Kolmogorov-Smirnov Test with the assistance from the SPSS 20.0. The results of the normality test might be consulted in Table 6 .

Table 6. Summary on the Results of Normality Test

\begin{tabular}{cccccc}
\hline \multirow{2}{*}{ No. } & \multirow{2}{*}{ Kelas } & Data & \multicolumn{3}{c}{ Kolmogorov Smirnov } \\
\cline { 3 - 5 } & & & Statistics & Sig. $(\mathrm{p})$ & Status \\
\hline 1. & Experimental & Standard Gain & 0.11 & 0,20 & Normal \\
2. & Control & Standard Gain & 0.16 & 0,05 & Normal \\
\hline
\end{tabular}

From the results in Table 6, it is apparent that the significance value (p-value) for each group has been higher than 0.05 ( $p>0.05$ ). Therefore, it might be concluded that the data in the study have been normally distributed. As a result, the assumption for the conduct of the independent sample t-test is met. 
Psychology, Evaluation, and Technology in Educational Research, 1 (2), 2019, 102

Sri Suriawati, Mundilarto Mundilarto

Table 7. Summary on the Results of Homogeneity Test

\begin{tabular}{lcc}
\hline \multicolumn{1}{c}{ Data } & Significance of Critical Thinking Skills & Status \\
\hline Based on Mean & 0.95 & Homogenous \\
Based on Median & 0.81 & Homogenous \\
Based on Median and with adjusted df & 0.81 & Homogenous \\
Based on trimmed mean & 0.95 & Homogenous \\
\hline
\end{tabular}

The homogeneity test is performed in order to identify the variance homogeneity for both groups. The results of the homogeneity might be consulted in Table 7. Departing from these results, the researchers have found that the standard gain value earns the significance value tat has been higher than $0.050(\mathrm{p}>0.05)$. Therefore, it might be concluded that the variance from both groups is homogeneous.

Based on the criteria of normality and homogeneity for the gain score, the hypothesis test that should be performed is the parametric statistical test. Specifically, the parametric statistical test that should be conducted in the study is the independent sample t-test by means of SPSS 20.0. In brief, the results of the independent sample t-test might be consulted in Table 8.

Table 8. Test on the Differences of the Students' Critical Thinking Skills

\begin{tabular}{lcrr}
\hline \multicolumn{2}{c}{ Standard Gain Score of the Students' Critical Thinking Skills } & \multicolumn{3}{c}{ Independent sample t-test } \\
\cline { 2 - 4 } & $\mathrm{t}$ & $\mathrm{df}$ & \multicolumn{2}{c}{ Sig. (2-tailed) } \\
\hline Equal Variances Assumed & 3.417 & 53.00 & 0.001 \\
Equal Variances Not Assumed & 3.422 & 52.80 & 0.001 \\
\hline
\end{tabular}

Based on the results in Table 8, it is apparent that the t-value in the two-tailed independent sample t-test for the gain score between the experimental group and the control group is 3.417 with the sig. (2-tailed) value 0.001 . The one-tailed independent sample t-test (right side) might be performed by dividing the significance value into two; consequently, the t-value is 3.417 with sig. (1-tailed) 0.0005 .

Within the conduct of the study, $\mathrm{H}_{\mathrm{o}}$ is rejected and $\mathrm{H}_{\mathrm{a}}$ is accepted because the sig. (1-tailed) value is $0.0005<0.05$. Therefore, it might be concluded that the improvement on the critical thinking skills of the students who have been exposed to the SETS approach-based audiovisual learning media is more effective than the improvement on the critical thinking skills of the students' who have not been exposed to the SETS approach-based audiovisual learning media. These findings are in accordance to the results of the study by (Afrianis, 2018), which conclude that the SETS method is able to improve the students' critical thinking skills.

\section{CONCLUSIONS}

Based on the results of the research and development study, it might be concluded that the SETS approach-based audiovisual learning media that have been developed are already in accordance to the criteria that have been set. The results of the assessment for the SETS approach-based audiovisual learning media show that the media falls into the "Very Good" category for the aspect of media and the "Good" category for the aspect of materials. The lowest achievement score for the students' critical thinking skills after the students have been exposed to the SETS approach-based audiovisual learning media is 0.25 , which falls into the "Low" category. However, the results of the statistical test for the SETS approach-based audiovisual learning media show that there have been differences on the critical thinking skills between the students who have been exposed to the SETS approach-based audiovisual learning media and the students who have not been exposed to the SETS approach-based audiovisual learning media.

This product might be maximally benefitted by both the students and the teachers so that they will be facilitated in understanding the concept of heat transfer. However, further development on the SETS approach-based audiovisual learning media should be pursued in the form of wider scale experiment and random sample selection since the product that has been developed is still limited to the learning materials of Heat Transfer. By doing so, the product feasibility for the conduct of general learning process might be identified. In turn, the SETS approach-based audiovisual learning media might also be designed for the learning materials of other topics. 


\title{
Psychology, Evaluation, and Technology in Educational Research, 1 (2), 2019, 103
}

\author{
Sri Suriawati, Mundilarto Mundilarto
}

\section{REFERENCES}

Abdulhak, I., \& Darmawan, D. (2013). Teknologi pendidikan. Bandung: PT. Remaja Rosdakarya.

Afrianis, N. (2018). Peningkatan keterampilan berpikir kritis siswa dengan menggunakan model inkuiri terbimbing bervisi SETS. Konfigurasi : Jurnal Pendidikan Kimia Dan Terapan, 1(2), 203. https://doi.org/10.24014/konfigurasi.v1i2.4316

Badan Standar Nasional Pendidikan. (2006). Standar isi untuk satuan pendidikan dasar dan menengah: Standar kompetensi dan kompetensi dasar SMA/MA. Jakarta: Badan Standar Nasional Pendidikan.

Binadja, A. (2006). Contoh model evaluasi pembelajaran bervisi SETS dan berpendekatan SETS. Semarang: Universitas Negeri Semarang.

Binadja, A. (2009). Pedoman praktis pengembangan model evaluasi pembelajaran bervisi dan berpendekatan SETS. Seminar Lokakarya Pembelajaran Kimia Bervisi Dan Berpendekatan SETS Bagi Guru-Guru Sains Kimia SMP Surakarta. Surakarta: Universitas Sebelas Maret.

Budiana, A. (2019). Pengembangan media pembelajaran digital sistem antena berbasis REACT pada mata pelajaran penerapan sistem radio dan televisi kelas XI teknik audio video di SMK Negeri 2 Singosari. Jurnal Edukasi Elektro, 3(1). https://doi.org/10.21831/jee.v3i1.25895

Gall, M., Gall, J. P., \& Borg, W. R. D. (2003). Educational research: An introduction (7th ed.). Boston: Pearson Education Inc.

Hake, R. R. (2002). Relationship of individual student normalized learning gains in mechanics with gender, high-school physics, and pretest scores on mathematics and spatial visualization. Physics Education Research Conference, 1-14. Retrieved from http://www.physics.indiana.edu/ hake/PERC2002h-Hake.pdf

Haryoko, S. (2012). Efektivitas pemanfaatan media audio-visual sebagai alternatif optimalisasi model pembelajaran. Jurnal Edukasi Elektro, 5(1).

Mardapi, D. (2008). Teknik penyusunan instrumen tes dan nontes. Yogyakarta: Mitrs Cendikia Offset.

Misbah, M. (2006). Taufiqul Hakim “Amtsilati” dan pengajaran Nahwu-sharaf. Insania, 11(3), 389407. Retrieved from http://ejournal.iainpurwokerto.ac.id/index.php/insania/article/view/207

Ngafifi, M. (2014). Kemajuan teknologi dan pola hidup manusia dalam perspektif sosial budaya. Jurnal Pembangunan Pendidikan: Fondasi Dan Aplikasi, 2(1). https://doi.org/10.21831/jppfa.v2i1.2616

Nitko, A. J., \& Brookhart, S. M. (2011). Educational assessment of students. New Jersey: Pearson/Allyn \& Bacon.

Poedjiadi, A. (2005). Sains teknologi masyarakat model pembelajaran kontekstual bermuatan nilai. Bandung: Remaja Rosdakarya.

Rusman, D. K., \& Riyana, C. (2011). Pembelajaran berbasis teknologi informasi dan komunikasi. Bandung: Rajawali Pers.

Setiawan, R. (2010). Analisis pengaruh faktor kemampuan dosen, motivasi belajar ekstrinsik dan intrinsik mahasiswa, serta lingkungan belajar terhadap semangat belajar mahasiswa di Departemen Matakuliah Umum Universitas Kristen Petra. Jurnal Mitra Ekonomi Dan Manajemen Bisnis, 1(2), 229-244. 